\title{
CHALLENGING HABERMAS' PRACTICAL DISCOURSE TO JUSTIFY THE RIGHTS OF ANIMALS
}

\begin{abstract}
The article is about to challenge Habermas' practical discourse approach and to explore its potentials for the justification of animal rights. Firstly, the classic concepts of agential features are discussed to examine whether animal agents deserve their rights (quasi sui juris in terms of $\mathrm{H}$. Jonas) or they should be unconditionally recognized as continuously present in and endangered by the human and social world (Sections 1, 2, 3). Secondly, the principle of universalization of rights employing practical discourse is revised and extended to create the most favorable communicative-discursive opportunity for advocating for animal rights and catalyzing an agreement upon their validity, to adopt them as a justified "new social norm", and so to overcome the limitations of practical discourse. Subsequently, Habermas' view on the rights of animals is discussed (Section 4). The authors try to contribute to the "therapeutic" discourse recommended by Habermas when the matter of practical discourse rises controversies.
\end{abstract}

\section{Keywords:}

animal rights, justifying the animal rights, challenging discourse ethics, practical discourse revised, animals and humans, J. Habermas 


\section{OBJECTIVES AND THEORETICAL FRAMEWORK}

Since practical discourse has been successfully applied to justify human rights and laws (Alexy, 1992: 234), the following question seems pertinent: why not extend this practice and apply it to justify the rights of animals? ${ }^{1}$ Today, the list of subjects with rights, or at least legal protection, goes beyond the class of subjects attributed with dignity, in the sense of autonomous self-determination. Why should we not consider animal agency having "legal standing" (Hodgson, 2010: 792) and even their preoriginal right to have rights, to use Arendt's language, consensually accepted by humans as fundamental to protect animals from ecocide and destructive impact of our societies (Keulartz \& van der Weele, 2009: 238)?

Since, after the era of the unlimited right to their own development at the expense of unprotected animals, people are now considering self-restraint. Granting animals the right to be guided by their own rights also makes sense in the context of the planetary environmental crisis. This idea may challenge the popular position on animal rights, which sees them as limited to natural determinisms and emanations of biotic habitats. However, in a human-dominated world, abusive practices towards animals are ubiquitous, so the legal failure to protect animals is a serious and global normative problem.

Since we have entered not only a post-metaphysical and post-traditional era, but a posthuman era, the limitations of practical discourse are to be challenged and its potentials explored to prove how discourse can facilitate social justification of animal rights. As anyone may "introduce any assertion into the discourse," "express their opinions, wishes and needs," state what they themselves believe to be a right and justifiable claim, and "problematise any assertion" (see Alexy, 1983, Part B; Habermas, 1983), examining validity of animal rights seems thoroughly possible in practical discourse. This chapter deals with this topic in the following way:

The revised principle of universalization will be considered, with an emphasis on the responsibility of discourse participants to recognise the rationale for why animals deserve to have rights. Instead of subordinating the interests of animals to their anthropocentric "best interests" (Habermas, 1990: 68; Altner, 1979; Böhler, 2014), discourse participants would justify animal rights by representing and acknowledging animals' "best interests" and balancing them with their own interests, which would no longer be anthropocentric. They would be guided by a modified principle of universalization.

Rather than ascribing as binding on everyone else a maxim that I can claim as a universal right for animals, I must present my maxim to all other participants in the discourse in order to argumentatively test its claim to universality for rational humans credibly representing (and first: adequately recognizing) the vital interests of animals in those socio-practical contexts that

\footnotetext{
${ }^{1}$ This article will appear in M. Gensler, W. Kazimierska-Jerzyk, K. Kędziora (eds.), Practica and Speculativa. Studies Offered to Professor Andrzej M. Kaniowski. University of Łódź Press, 2022. ISBN 978-83-8220-570-1, eISBN 978-83-8220-571-8.
} 
threaten the realization of those interests. As we know, the vital interests of all living inhabitants of the ecosphere are interlinked. Therefore, the interests of animals, "although they are not our interests, can 'affect' us even when we have no direct interest in them" (Somek, 2016: 80). The emphasis shifts from what each can will without contradiction to be a general norm, to what all can will in agreement to be a universal norm (cf. Habermas, 1990: 68; McCarthy, 1978: 326) extended on related nonhuman living beings, including the consequences implied by this norm for all animal and human beings. This version of the principle of universalization actually entails the idea of a cooperative process of argumentation' (Habermas, 1990: 68) in favour of solidaristically shared and to that extent commodified and generalizable interests, demonstrating that the claim to validity attributed to normative statements can be rationally and publicly examined within the framework of practical discourse.

However, the principle of universalization modified in this way would itself first require the acceptance of the participants in the discourse. We may note that this modification respects Habermas's requirement (see section 4) to distinguish between human persons and animals if it is true that "humans are 'persons' while animals are not" (Singer, 1978: 82), although they may possess natural agency (as discussed below).

As a result of this modification, the principle of universalization transforms itself to the principle of universalizability: human discourse participants would proceed so that their anticipated agreement upon the universal validity of animal rights does not involve asking animal subjects to deliver their reasons or arguments. First of all, the resulting discourse rules themselves need to be justified to ground a specific, animal normativity-oriented discourse procedure, as human participants would not necessarily have "intuitive knowledge" of the new rules (Habermas, 1990: 97)².

Obviously, animals will not participate and argue directly which thus fails to meet Habermas' criterion of the "equalization of power" by neutralizing imbalances of power (Habermas, 1990: 71-72) inside and outside of discourse. Therefore, discourse participants will be obliged to exchange their previous extra-normative power for normative power and to follow the new rule of practical discourse, as advised by Hans Jonas: "In order to give the nonhuman life its own right" (gewährt dem außermenschlichen Leben sein eigenes Recht) as quasi sui juris (Eigenrecht) (Jonas, 2015: 183) - minimize your claims to excessive anthropocentric power monopoly (das anthropozentrische Monopol) over the biosphere. Instead, extend the scope of your responsibility for future life to the planetary scale (Jonas, 1987: 87-88). Such a normative shift would derive from interspecies solidarism, reframe practical discourse to justify animal rights and balance powers in a biocentric (and therefore no longer anthropocentric) way (see Stilt, 2021).

Furthermore, while using their cognitive and rational-discursive advantage over animals to argue in favor of their rights, human discourse participants will be obliged to revise their epistemologies and knowledge regarding animals in accordance with the state-of-the-art science (which might be demanding for many discourse participants - and this is why we argue for scholars' engagement in discourse which 'takes its place among the reconstructive sciences

\footnotetext{
${ }^{2}$ Working on "the certainty with which we put our knowledge of rules into practice" (Habermas, 1990: 97) of seeking a discourse-based justification and agreement on the animal rights belongs to discourse theory research.
} 
concerned with the rational bases of knowing, speaking, and acting" (Habermas, 1990: 98). Also "moral philosophy does have an enlightening or clarificatory role to play vis-a-vis the confusions that it has created" (Habermas, 1990: 98) in line with the development of human moral consciousness including advances in recognizing animal rights' validity.

At the same time, discourse participants will act as exponents and advocates of the best interests (and reasons, see Section 3) manifested by animal behavior, in order to transform the claims to validity of a series of legal rules to the validity which always only anticipates an ideal validity.

Applying practical discourse procedure to ground animal rights as universalizable seems possible (Mendieta, 2011), though the authors realize that "convincing the public of the necessity of adopting a new social norm and obtaining the consensus to enact the changes required is going to be a long, slow process" (Sankoff, 2012: 319). Challenging the "limitations of practical discourses" (Habermas, 1990: 107), exploring the potentials of discourse ethics both encouraged by Habermas - and creating a favorable communicative-discursive opportunity to convince someone by arguments to adopt animal rights as a firmly justified, "new social norm" (Sankoff, 2012: 319) would be initial in this process.

In his article "Filozofia praktyczna Immanuela Kanta - jej siła i słabości" (Immanuel Kant's Practical Philosophy - Its Strength and Weakness) A. M. Kaniowski (2004) reflects on Kant's statement that "Everything in nature works according to laws", but "Rational beings alone have the faculty of acting according to the conception of laws, that is according to principles" (see also Fieldhouse, 2004; Skidmore, 2001). Accepting Professor Kaniowski's "invitation to discuss the topic", we decided to challenge the limits of the "mundus intelligibilis" (even in its 'situated' and 'embodied' formulas) and try to "incorporate other animals than humans" (Łuków, 2004: 138) into the realm of principles conceptualized by humans to recognize laws according to which the animals work - at least the basic ones.

\section{IS RIGHT AS A “CONCEPT OF POSSIBLE FREEDOM” POSSIBLE FOR ANIMALS?}

Due to their different "natures", animal and human rights were usually claimed to be discrepant. According to Kant, subjects are free if, and only if they embody self-consciousness and selfidentity; the remaining subjects seem not to be identical with themselves and are "diffuse in nature" (Adorno, 1970: 292).

However, approaching the right as a concept of freedom, Kant and Fichte also addressed the causal, manifest (das Recht, freie Ursache zu sein) and external freedom of an individual only limited by the freedom of fellow individuals. This mutual limitation was further conceptualized, as common and binding (Wechselwirkung nach Begriffen) (Fichte, 1979) for subjects governing their freedoms by virtue of the concept of right.

Gegenseitiges Freilassen, und die ganze künftige Erfahrung müssen Eins, und ebendasselbe sein, oder, deutlicher, in der gegenseitigen Freilassung muß schon die ganze künftige Erfahrung, welche begehrt wird, liegen (Fichte, 1979: 100). 
"The whole prospective experience" of acting in accordance with the concept of the reciprocal allowance to use individual external freedom captures the sense of collective selfregulations. Even more: it anticipates Rawls' initial principle of justice: "each person is to have an equal right to the most extensive basic liberty compatible with a similar liberty for others" (Rawls, 1971: 60). With causation and extensive liberty, Kant, Fichte and Rawls approach physical laws and natural behavioral causation.

However, no such reciprocity and community of rights or laws can be expected between human and animal subjects. However, each of them shows an innate "drive" to self-activity and self-determination on their own ground (Trieb nach Selbständigkeit) (Fichte, 1995: 218), be it spontaneous, instinctive and "blind" in natural creatures (Naturwesen) or deliberate and guided by rules in rational creatures. This agential feature of nearly all living beings was also explored by Spinoza, even in terms of the plurality of rights, beyond the gap between nature and reason:

It is a right that Spinoza ascribes to every individual, not just rational or human beings, and it is a right that implies no reciprocal claim on the part of other individuals to respect it [...] a claim that would appear to eliminate any distinction between the natural and the normative, or between how an individual is determined to act and how it ought to act (Rutherford, 2008: 489).

Although not having rejected reason itself, Spinoza radically revised its claim to justify and prescribe rights by means the "pure" practical reason and transcendental deduction. As a result of this naturalistic turn, humans would prescribe "'rules for living' to themselves or others. Once decreed, these laws offer significant practical advantages" (Rutherford, 2010) with reference to "what we certainly know to be useful (esse utile) for us" (Spinoza, EIVd1), or others. What is useful (or "good") for human and nonhuman beings, can strongly differ, so it is a mistake to claim all species harmoniously share natural goodness (or the related laws). "Because of the difference in nature between humans and nonhuman animals" (Grey, 2013: 379), what is unconditionally good for the latter, can only be situationally good for the former, and vice versa. However,

the denial of perfectly shared natures does not entail the denial of all morally relevant similarities between individuals. Just because animals do not share a nature does not mean they are dissimilar in every morally important respect [...] all of which might bear some degree of morally important similarity to us (Grey, 2013: 382; cf. Wilson, 1999).

Here we come to the normative discrepancy that poses a challenge for humans: granting rights to animals would imply that humans accept specific self-commitments regarding animals. These self-commitments would encompass not only recognizing - and respecting - animal rights as valid (in terms of theoretical and practical discourse), but would also amount to selflimitation, thus, sacrificing certain interests (usually justifying human strategies and powers) for animals' sake as a part of consensual action.

In fact, "the legitimate interests of animals and the legitimate interests of human beings are in conflict in some [...] areas" which intensifies "the enforcement gap" (Sunstein, 2002). Dealing with the discrepancy would advance the participants of discourse from "naïve" and "controversial" claims to solutions that are normatively relevant and acceptable for all of them (was alle in Übereinstimmung als universale Norm anerkennen wollen) (Habermas, 1993: 77). 
Rights that animals would be entitled to under the condition of justification obtained by means of practical discourse seem not to exclude a normative concept of freedom tailored to animals (Grey, 2012; Wilson, 1999; Horster, 1989). Still, Kant explicitly talked about "subsidiary" self-commitments and "duties to animals, that is, we do have duties to animals, but only as a proxy for duties towards other humans" (Mendieta, 2011) on account of the different "natures", interests (and agential faculties, as discussed below). Homogeneous and symmetrical rights and duties to bridge an interspecies gap do not seem to be part of a realistic project (Pietrzykowski, 2019) for Spinoza either, who found that none of the "natures" were ideal, and thus none were entitled to regulate the universe of life.

The above discussed arguments have demonstrated that the German philosophers attempted to diminish the anthropocentric hegemony over human and nonhuman animalia but failed to rule out the concept of animal rights (legislated animal natural laws, respectively) (Nowak, 2021).

Nowadays, ordo amoris (Scheler, see Kelly 2011), animal liberation, freedom from suffering, welfare and wellbeing (e.g., in P. Singer ${ }^{3}$ ), eco-solidarity (e.g., in Probucka, 2018), or cosmopolitanism (Mendieta, 2010) are classic arguments to justify animal rights, however, their persuasion power shows limitations ${ }^{4}$. On the other hand, arguments pertaining to inherent value of animals (Regan, 1983) and their dignity seem to construct a new animal metaphysics.

\footnotetext{
Rawls' theory of justice does not seem to offer normative tools to restrict the injustice practiced by humans toward animals. 'No one needs ask the question: 'What if I were born an animal? How would I like to be treated then?' (Probucka, 2017: 161).
}

Speaking of the entire philosophical tradition, Derrida accuses it of having deliberately forgotten the animal, and along with it the very animality of human beings" (Grondin, 2007; Derrida, 2008).

In the subsequent Sections (3 and 4) we will take a different path. Animal agential features shall be revisited to then revise - or even extend - Habermas' approach to animal rights. Then, with Mendieta, we shall go the next step in order to show that the social/ethical discourse procedure is the best one for considering and justifying animal rights, because animals are not only omnipresent in the human and social life worlds (or the human and social life worlds are omnipresent in animal life worlds), but are also radically affected by human and social practices. Thus, we, humans, are present within the external natural world with our overexpanding self-determination and self-fulfillment; and the latter should be autonomously self-limited (not just "annihilated") when recognizing the animal right to self-determination and self-fulfillment. Thinking beyond dichotomies and dualisms, we hope to harmonize the worlds, instead of deepening the antagonisms between them. To put it in Kantian terms, the regularity

\footnotetext{
${ }^{3}$ As a consequentialist implication of J. S. Mill's statement: "the question is not, can they reason? Nor, can they talk? But, can they suffer?" (Mill, 1987: 252).

${ }^{4}$ For instance, ,,one cannot feel obligation towards a thing that does not possess an emotional life in which one can take part. One neither feels-with or sympathizes (Mitfühlen) with a lobster or a clam, nor condemns or respects it morally," however, once one has learned that a lobster possesses an emotional life so it can suffer, one is more likely (and enabled) to recognize it as a moral fellow. "Since entry into our fellows' inward life is a condition of our sense of obligation to and solidarity with them, sympathy has a moral function. Lack of sympathetic awareness of others breeds alienation and indifference, and leads to considering them as strangers whose life we do not share" (Kelly, 2011: 49). This example shows why a contingent perception and openness to others, as well as a conditional recognition of others remain casual, but not a common and firm basis of a moral status.
} 
[Gesetzlichkeit] of nature and that of reason represent "the starry heavens above and the moral law within me" (compare Mulia et al., 2018).

\section{ANIMAL AGENTIAL CAPACITIES. PHILOSOPHICAL ARGUMENTS TO SUPPORT THE INITIAL CLAIM TO THE VALIDITY OF ANIMAL RIGHTS}

Firstly, we will collect strong arguments to provide the concept of animal rights with a provisional claim to validity. We found two strong arguments in Jonas' approach to the organism as a "distinct unity", "inside knowledge", "affectivity", "spontaneity" and "autonomy" as "a capacity of organic form [...] to change its matter", "biological behavior", "productive performance" and "internal identity as the subject of its existing in actu" very different from mechanical and lifeless; "exercising itself in seeking or avoidance"; selftranscending and self-actualizing "its continued existence"; making "the point of life itself: its being self-centred individuality, being for itself and in contraposition to all the rest of existence, with an essential boundary dividing "inside" and "outside" - on the bases of actual change" (Jonas, 2016: 45-58). "In this polarity of self and world, of internal and external [...] the basic situation of freedom with all its daring and distress is potentially complete" (Jonas, 2016: 54). "Organic individuality is thus adventure, in which immediacy of being has been forsaken for the mediacy of execution" (Jonas, 2016: 48). Also, it has "inwardness", that is, "the unity of the individual subject of life" (Jonas, 2016: 58). Focusing on self-determination, integrality and individuality, Jonas' concept of a living organism anticipates - or even surpasses - the present-day conceptualizations of animal agency ${ }^{5}$.

P. Foot developed the concept of animal moral agency, thereby allowing us to define animal moral status more precisely, with the addition of new features. With regard to normative implications, if humans were to take these features into account, the vast majority of them would probably refuse to inflict cruelty and experimentation "upon a member of our own species with similar potentialities" (Singer, 1979: 82; see also Chapouthier, 2013). According to Foot, animals incorporate practical pre-rationality, which cannot be derived from the goodness of their will, but from reasons for acting that make their actions important. Following their reasons, they manifest their preferences. Approaching their behavior in this context, we can easily identify and transform material values of "sub-rational things" to their reasons for action, and to validity claims ascribed to our assertion (judgment) on this. Furthermore, Foot talks about "autonomous", "intrinsic", "natural" features and

\footnotetext{
goodness [...] that may have nothing to do with the needs or wants of the members of any other species of living thing [...] Judgements of goodness and badness can have, it seems, a special "grammar" when the subject belongs to a living thing, whether plant, animal, or human being [...] Natural goodness [...] is attributable only to living things themselves and to their parts, characteristics, and operations, is intrinsic or "autonomous" goodness in that it depends directly on the relation of an individual to the 'life form' of its species (Foot, 2001: 26-27).
}

\footnotetext{
${ }^{5}$ In this article we only refer to the ipseity of an organism, however, Jonas offers much more, e.g., lectures on organism by Spinoza. For instance, he defines intentionality as a "decisive feature which represents the animal translation of the basic »concernedness « of all life, and it imbues animal sentience - perception - and animal motility - perception-guided motion - equally" (Jonas, 2016: 63).
} 
Foot also recalls P. Geach's maxim referring to the evolutionary and analogical affinities between the human and the animal sense of justice or charity: "Men need virtues as bees need stings", which is crucial for the cooperative life forms of numerous species.

With Michael Thompson's study The Representation of Life we go beyond Foot, to meet Kant and Habermas. All life-forms, Thompson argues, incorporate a specific intelligent ability to follow reasons (or principles, as is the case with human beings) which make up their speciesspecific practical rationality. Kant has demonstrated

\footnotetext{
systematically how this principle "applies" to specifically human beings, that is, to fellow bearers of the terrestrial life-form or species that he himself exhibits. So even here concepts allied to those of life and life-form make themselves felt [...]. And so, for example, if we care to contemplate kinds of reasoning animals other than our own, as Kant constantly implicitly did, shouldn't we be prepared also to imagine different shapes of practical reason? (Thompson, 1979: 28-30)
}

and to recognize them (Thompson, 2011).

Let's consider nonhuman species in terms of their natural "normative authority". Thompson unequivocally advocates for animal "rational agency" instead of values or - alternatively biological processes. Neither values nor biological processes can be applied to justify animal rights through discourse procedure. Instead, to better understand how an animal's "rational agency" behaves, Foot advises considering it not in times of stability, but under circumstances involving the damage and harm caused by human practices. "A strength or a weakness in a living thing cannot be identified in the same way as, say, hardness or softness in a rock" (Foot, 2001: 35-36). Animals are bound without alternatives to their way of life and are unable to consciously determine a new lifestyle (let alone choose an ideal of the good life) (Kant, 2013: 167), but are nevertheless able to change their actual behaviour on the basis that they have changed their minds and learn new ways of behaving. Hence, they manage their causal and agential capacities and are not entirely predetermined by behavioral automatisms, external regularities, overpowering instincts, or god's voice, as Kant puts it. (Here the Kantian scheme according to which every thing in nature acts directly according to regularities, and only rational beings - that is, non-natural beings - act according to the representation of laws, loses its sharpness; for neither natural beings are purely natural, nor are rational beings purely rational in their activities). This is what Foot already has approached as the natural shape of practical reason in animals. Ch. Korsgaard has referred to these ideas and their normative consequences, which are mainly disrespected by societies: "Because the other animals do not choose their own way of life, they do not have rights grounded in this kind of autonomy" (Korsgaard, 2013: 30). She then advocates for protecting the existence and autonomy of animals "from us, from human beings" (Korsgaard, 2013: 31). The way we can cooperatively do so as a society "is by making laws" (Korsgaard, 2013: 31). And the way we can cooperatively justify such laws and lawmaking is, in our opinion, practical discourse.

How could this argument support the reasonings necessary to improve the claim that animal rights have validity within discourse? Firstly, taking it into account would result with the depotentiation of human practical reason, which has been considered unique and dominant since Plato's era. The embodied, intersubjective and social modus of practical reason provides the strongest anthropocentric foundation of discourse. But to argue for the validity of animal 
rights, the interest of human practical interest is not central; instead, procedure is central. Secondly, unveiling natural practical reason as the central agential feature of animals (in Foot's terms) weakens one of the most powerful counter-arguments against animal rights. According to this counter-argument, people strive to grant rights to animals in order to realize the interest of their own, human practical reason. The goal of animal rights advocates - as their opponents claim - is therefore not to eliminate the harm done to animals and to foster animal wellbeing. It is a human moral ambition: to ennoble one's own humanity or to reject speciesism: "our neglect of the interests of members of other species with equal or superior capacities is mere 'speciesism' - a prejudice in favor of 'our own kind' that is analogous to, and no more justifiable than, racism" (Singer, 1978: 82).

However, Foot's argument shifts the emphasis from the human moral aspiration (become better to animals, advancing human ecological virtues, etc.) to animal interest: more specifically to the animal's right to existence free from harm and mistreatment, and to the right to selfdetermination, development and self-fulfillment. Foot's argument also frees the concept of animal rights from a certain misunderstanding. This is based on the idea that animal rights have a moral character, imposed on animals by humans and, consequently, that they are anthropomorphous. However, the argument to justify animal rights within discourse, as an argument referring to animal practical reason, does not in fact prescribe any moral behavior to any animal subject. It prescribes such behavior to human subjects, however, with the focus on animal subjects as the moral ends of humans, though not all instrumental treatment conflicts with this focus.

Such a re-evaluation of animal agential capacities based on the above discussed arguments, especially because "an animal's consciousness can be entirely practical” (Korsgaard, 1989: 118) or sub-practical would significantly contribute to the concept of animal rights (Garner, 2008; 1996) not only in terms of "negative claim-rights" (i.e. "the withholding of something, namely, the interference of another”) (Puryear, 2017: 8), but also in terms of positive claim: „to have a right in this sense is just to be capable of being wronged" (Puryear, 2017: 8). The re-evaluation would also imply downscaling a practiced anthropocentric supremacy, i.e. the normative predominance of the human agent as a participant of discursive procedure.

Taking into account, that nonhuman living beings

1) are capable of self-determination and self-fulfillment (to specific extent), they thus embody agential abilities in a scope and type appropriate to their species;

2) they are constantly present in the human-social horizon of experience and practice, most often in a position of wronged (not just reified and instrumentalized), at the same time

3) being incapable of communicative and discursive self-constitutionalization (i.e. the process of organizing 'societas' together with other individuals), as well as participation in the constitutionalization of mutual relations and cooperation with people;

Furthermore, taking into account that

4) the natural habitats of animals not only come into contact with and interpenetrate humansocial environments, but the former are radically reduced and transformed by the latter, in 
accordance with human priorities (which are usually strategic), animals are therefore not able to negotiate their rights to their natural habitat ${ }^{6}$ with human beings.

The following socio-normative question thus seems legitimate: how can we regulate this zone of inter-species tensions and abuse (on the part of human beings) by using communicativediscursive rationality and norm-forming-legitimizing practical discourse? G. Patzig (1984) accused Habermas' discourse theory of excessive anthropocentrism. The present article draws on Patzig's argument to the extent that it poses a central question for animals: namely, the question of the rights that enable them to achieve the previously mentioned self-determination, self-fulfillment, and development. In turn, the establishment of, and respect for, such rights for each considered animal lies within the remit of human rational and communicative-discursive competence.

Both these processes, that is, self-determination and self-realization, have already been defined for human beings, for instance, in terms of 'capabilities'. It is possible to define capabilities, insofar as this encompasses well-being and development, also for animals that live in spaces shared with humans. In this case, animal rights would not only be a "principled account of how the capabilities view ought to deal with difficult questions" (Nussbaum, 2001: 1543) pertaining to animal functioning in the world dominated and controlled by humans. Above all, they would be the key normative guarantor of external, that is, environmental opportunities ("external conditions" in Nussbaum's terms) favorable for the individual, interindividual and intraindividual qualities of animal life (e.g., Ward et al., 2020). These opportunities can be considered in terms of "capabilities" (Nussbaum, 2018; Schinkel, 2008), on the supposition that concepts such as development, self-determination and self-fulfillment will be interpreted concurrently with the thoroughly recognized, correct and full-scale development of an individual within a population or species, as well as in other circumstances, such as relationships with humans, "for each species has its own good" (Nussbaum, 2001: 1542; Nussbaum, 2018).

Regulations are therefore needed exactly where people need them: at the inter-species interface of external freedom, where the ways of self-realization and self-fulfillment of individual subjects or groups conflict with the self-determination, development and selffulfillment of nonhuman subjects. Furthermore, one of the human "capabilities" was defined by Nussbaum as "respecting the diversity of animal lives" or, more exactly, as "being able to live with concern for and in relation to animals, plants, and the world of nature" (Nussbaum, 2018: 9). However, this 8th capability "must be considered utopian" (Schinkel, 2008: 49).

The authors are aware that the theory and practice of discourse do not serve to define "capabilities" or "thresholds". They do, however, serve to articulate, test, and legitimize certain rules that concretize the "concept of possible freedom" in its real and external realizations. It may be a challenge to define the basic realizations that are due to and preferred by animals as meaningful in normative terms. But such a challenge has already been taken up, in the attempt to define, for instance, The Five Freedoms approach:

\footnotetext{
6 "The animal does not reflect on the fact that its surroundings are only its surroundings, i.e. that it is relativized to its specific organization. This is because no animal thinks about something "outside" of this environment, that is, about the world in which it itself is part of the environment of another living being" (Spaemann, 2001: 79). Only people are aware of this.
} 
The Five Freedoms consist of the freedom from hunger and thirst, from discomfort, from pain, injury or disease, from fear and distress, and the freedom to express normal behaviour (Richter \& Hintze, 2019: 2).

In their developed, socially and environmentally located, but also conscious self-knowledge, human participants in discourse should try to properly represent and articulate such priorities and formulate a range of normative arguments in favor of animals' right to have rights.

Perhaps the greatest obstacle to such discourse will be the same strategic and egocentric interests that block the virtualization of the claims to validity in discourses concerning human interest. Let us now to place the spotlight on Habermas' position on animal rights.

\title{
HABERMAS ON ANIMAL RIGHTS
}

\begin{abstract}
It is just as difficult to answer the basic objection of ecological ethics: How does discourse ethics, which is limited to subjects capable of speech and action, respond to the fact that mute creatures are also vulnerable? Compassion for tortured animals and the pain caused by the destruction of biotopes are surely manifestations of moral intuitions that cannot be fully satisfied by the collective narcissism of what in the final analysis is an anthropocentric way of looking at things,
\end{abstract}

we read in Moral Consciousness and Communicative Action (Habermas, 1990: 206-207). In his subsequent works, Habermas seems to remain focused on animal vulnerability as the very foundational reason for humans to take animal rights into account. In "Remarks on Discourse Ethics" this reason is re-examined and defended against the criticisms formulated by scholars - in particular G. Patzig - who claimed that discourse theory and discourse practice are limited to anthropocentric interests and rights, with no platform for conceptualizing and justifying the position that animals have the right to be protected from cruelty, or for extending human moral responsibility to encompass the protection of animals from maltreatment ${ }^{7}$.

Habermas counter-argued from the human "quasi-moral" duty of cruelty avoidance:

We have an unmistakable sense that the avoidance of cruelty towards all creatures capable of suffering is a moral duty and is not simply recommended on prudential considerations or even considerations of the good life [...] Animals confront us as vulnerable creatures whose physical integrity we must protect for its own sake (Habermas, 1994: 106),

that is, a specific animal "normative authority" or "dignity" (Mendieta, 2011).

Mendieta has examined Habermas' argument, especially the qualitative difference between animal and human suffering. However, instead of making reference to the conscious pain and suffering which has recently been discovered in a large number of species, Habermas referred to humanist psychology, especially to the concept of psyche, person, self and identity; their vulnerability, and their disintegration, which may produce suffering incomparable with that of animals, who only experience "physical" disintegration.

"The person develops an inner life and achieves a stable identity" and integrity which are vulnerable and need to be protected by moral principles and human rights.

\footnotetext{
${ }^{7}$ Patzig asked: "Is it possible to extend the sphere of validity of moral obligation beyond the human realm to encompass all living creatures who are capable of experiencing pain and suffering but also pleasure? [...] We run up against a clear barrier [...] for animals cannot enter into relation of principled reciprocity with us of the kind that govern our conduct toward other human beings" (Patzig, 1984: 67, translation after Morar, 2008: 151).
} 
From this anthropological point of view [...] [m] oral institutions tell us how we should behave towards one another to counteract the extreme vulnerability of the individual through protection and considerateness. Nobody can preserve his integrity by himself alone [...] Morality is aimed at the chronic susceptibility of personal integrity implicit in the structure of linguistically mediated interactions, which is more deep-seated than the tangible vulnerability of bodily integrity, though connected with it (Habermas, 1994: 109)

His argumentation cannot support animal rights and corresponding human duties to respect and apply such rights, for several reasons. Firstly, animals do not manifest the integrity and dignity associated with human personality, and thus do not deserve institutionalized normative protection. Secondly, human duties and responsibilities towards animals cannot be justified by reciprocal and symmetric relations, which are only possible between human subjects, and are missing in human relations with animals because of the lower status of the latter. Hence, animals cannot be equal partners in intersubjective relations that are crucial for communicative action and practical discourse, which are the sources of the reciprocal recognition of the validity (Geltung) of all resulting rules, commands, obligations and agreements. Animals are not sociomoral, communicative and discursive agents (Morar, 2008: 152; Pietrzykowski, 2019). Therefore, "like moral obligations generally, our quasi-moral responsibility towards animals is related to and grounded in the potential harm inherent in all social relations", Habermas admits (Habermas, 1996: 109), and not in discursive procedures ${ }^{8}$. Here his whole argument:

Clearly this difference between personal and bodily integrity disappears in the animal world because we do not attribute personality to creatures with whom we cannot speak and cannot come to an understanding about something in the world. Nevertheless, we communicate with animals in a different wat once we involve them in our social interactions, in however asymmetrical fashion. Such interactions take on a measure of continuity in our association with domestic animals: our conscience is particularly insistent "concerning species with which we can communicate with particular ease" (Habermas, 1994: 109).

According to argumentation discussed by Ch. Korsgaard, Habermas' statement would originate from

the reason most frequently offered [...] that human beings just are more valuable and important than the other animals $[\ldots]$ we should ask ourselves, on what grounds do we ourselves claim to be valuable in the way that we claim to be - ends in ourselves, never to be used as a mere means to someone else's ends? $[\ldots]$ we should treat the other animals as ends in themselves. [Regardless of the fact that] The other animals lack normative self-government, and in that sense they are not persons (Korsgaard, 2014: 31; see also Rowland, 2016; Whitebook, 1979; Regan, 2010).

It's no secret that Habermas is not inclined to discuss values and evaluations within discourse ${ }^{9}$. When excluding animals as equal partners of communicative and discursive

\footnotetext{
${ }^{8}$ This conclusion suggests turning to deliberative procedure when issues cannot be resolved by means of the communicative-discursive model. But deliberative procedure is said to "underestimate the rationalistic bases of animal rights philosophy" (Garner, 2016).

${ }^{9}$ Although mentioning values, evaluations, "strong preferences", etc., and allowing subjects to access discourse when being oriented towards their "intrinsic" values (or sharing them with others), Habermas excludes values from discourse. "Since Aristotle, important value decisions have been regarded as clinical questions of the good life" and "strong evaluations can be embedded in the context of a particular self-understanding" (Habermas, 1993: 45), claims to validity instead of claims to value can be considered within discourse. Habermas consequently maintains values to be discourse-heteronomous and extraneous. There cannot be reasonably cognized and agreed upon values within a practical-discursive framework.
} 
situation, he refers not to animals' self-governance, but to their functional disability, which entails that the reciprocity and symmetry required to justify normative claims remain unattainable.

But do discourse participants discussing animal rights need a concept of animal personality and its integrity (especially in terms of moral personality/integrity) to reorient and extend their moral responsibility towards the animals' desire to be free from harm, suffering and animalscale disintegration ${ }^{10}$, e.g., post-traumatic disorder (Whitaker et al., 2014; Neumann et al., 2011; Nussbaum, 2018)? On the one hand, we need updated evidence- and observation-based knowledge to develop proper cognition on human vs. animal experience with suffering and disintegration, including pluralistic epistemologies to approach biodiversity. On the other hand, however, we need "a pluralism of value orientations" (Habermas, 1990: 76) to enter a discourse procedure that would lead to the recognition of animal interests, so as to improve and legitimate conventions for animals, just as we do so for diverse interest groups living in a pluralistic society. For several reasons, this might be challenging for humans, but

Even if we are not able to reach "understandings" with them [animals - E.N. et al.], they are embedded within social relations within which they are vulnerable to the potential harm that is part and parcel of every social interaction. But how are these moral claims embodied in our social interactions? How do our moral intuitions take shape in social institutions and direct our social interactions? This is what Habermas set out to answer in his Between Facts and Norms (Mendieta, 2011).

It is not conventions themselves which are "moral". Once the communicative interaction allowed an interhuman reciprocal understanding of what the animal rights concept means and implies in terms of descriptive and normative aspects, the best quality moral arguments, reasons, beliefs, etc. will be delivered and examined to transform the animal rights' claim to validity into validity. Arguments are often based on moral principles and evaluations, but legal conventions (laws or "administrative powers") and moral principles/evaluations are different phenomena. Again, "moral" (in other words: right/righteous) would refer to an obligation that is accepted and followed by subjects for the same reasons they approved making it valid as "moral" lawgivers.

Therefore, according to Habermas, law remains "the only medium in which it is possible reliably to establish morally obligated relationships of mutual respect even among strangers" (Habermas, 1996: 460) and those who are radically other, including the representatives of diverse species. Again, rights - not laws - "is the way we experience law, embody moral intuitions while also guiding our everyday interactions in a non-coercive way that nonetheless regularizes our mutual expectations" (Mendieta, 2011). Observing rights (or general principles which make up the powerful arguments within practical discourse) one behaves as moral subject. Following laws, including their coercive ways of bringing about social conflict resolution and punishing the violation of laws, sanctions, etc., one behaves legally. Analogous

\footnotetext{
${ }^{10}$ Recent findings between 2001-2020 show that central to the development of "animal personalities", in terms of the research subject, "was the accumulating evidence that behaviour is much less flexible than previously thought and that individuals of the same species differ consistently from each other concerning their behavioural and physiological patterns. Despite this increasing interest in the animal personality concept, however, there is still a great deal of uncertainty and debate about how to best conceptualise it" (Richter and Hintze, 2019: 1; see also Powel et al.; 2011; Gosling, 2001).
} 
to human rights, animal rights show their dual-nature, their "Janus face", "simultaneously turning to law and to morality" (Habermas, 2010; cf. Mendieta, 2011).

What counts in participating in discourse to achieve a normative agreement with regard to establishing animal rights as universally accepted and valid legal conventions (laws), is the competence to justify. We will not only improve the moral right to the justification of animal rights (speaking with R. Forst) in ourselves, but also our competence to justify such rights with serious moral reasons, making them "non-rejectable, universally valid, and applicable in particular cases" (Forst, 1999: 36), in analogy with human rights.

\footnotetext{
The issue is not whether animals are rational, and thus command the respect every rational entity commands. Nor is it whether animals can communicate, or enter into our "space of reasons," and thus hypothetically at some point assent to the consequences of the enforcement of some rights,
}

as Mendieta (2011) argues. The issue is whether we are rational and respectful enough to initiate discourse situations of all the kinds mentioned in discourse theory, whose participants argue by means of reasons and principles (not only by intuitions, human-centered interests, or strategies).

\section{CONCLUSIONS}

The arguments, analyses and references to discourse theory discussed above, as well as the discursive procedure of justification in regard to animal rights, are not intended to provide a new or revised discourse approach. The authors' ambitions were modest. They are hoping to meet J. Habermas' expectation with regard to philosophers: "in the political forum of a given democratic society, the philosopher's proposed explications can have at most a catalyzing or clarifying function" (Habermas, 1996: 60) in order to prepare some bases - if not for "a rationally motivated agreement" through discourse, then for facilitating rationally motivated reflection or deliberation on the question, how can we better justify animal rights to bring them into juridical reality, that is, to empirically existing and applicable laws?

Nevertheless, in sum, we can conclude as follows: the discourse theory developed by Habermas shows potentials to be adapted and applied as a justification procedure of animal rights. Habermas - like many scholars representing nondiscursive ethics - does not recognize animal moral agency, and animals are absent in interhuman discourses. However, the animal agency concept is evolving and the chance for proper representation of the animals' "best interests" by humans (or the chance to harmonize animal and human interests) is developing alongside increasing scientific and normative awareness. Promoting the latter to unmask and to diminish the heterogeneous powers applied to animals (Chrulew \& Wadiwel, 2017); in other words, to diminish a practiced predominance of the human normative (and natural) agency should be one of the priorities of discourse theory and discourse ethics interested in the justification of animal rights. At the same time, a rational communicative and discursive community cannot be replaced merely by solidarity and community between human and nonhuman animals (Böhler, 2014: 461). Discourse participants are expected to deliver rational and normative arguments to convert the claims to validity of animal rights to validity. In so doing, they would be able to protect valid normativity against quasi-normativity derived from the descriptions of biological life not belonging to the horizon of questio juris (Böhler, 2014: 
462-463). Among these descriptions, however, exemplifications of animal descriptive bioethos can be found ${ }^{11}$. For this reason, discourse participants genuinely should approve animals "as individuals in their own right" (quasi sui juris) (Alexy, 1992: 238).

\section{BIBLIOGRAPHY}

Adorno, T. W. (1970). Negative Dialektik. Frankfurt am Main: Suhrkamp.

Alexy, R. (1983). Theorie der juristischen Argumentation. Frankfurt am Main: Suhrkamp.

Alexy, R. (1989). “The Special Case Thesis". Ratio Juris. An International Journal of Jurisprudence and Philosophy of Law, vol. 12, no. 4, pp. 374-384.

Alexy, R. (1992). „A Discourse-Theoretical Conception of Practical Reason“. Ratio Juris, vol. 5, no. 3, pp. 231-251.

Altner, G. (1979). „Wahrnehmung der Interessen der Natur“, in: Mayer-Abich, K. M. (ed.), Frieden mit der Natur. Freiburg in Breisgau: Herder.

Arendt, H. (1973). The Origins of Totalitarianism. New York: Harcourt Brace Janovich.

Böhler, D. (2014). Verbindlichkeit aus dem Diskurs. Denken und Handeln nach der Wende zur kommunikativen Ethik - Orientierung in der ökologischen Krise. Freiburg-München: Verlag Karl Alber.

Chapouthier, G. (2013). „Thoughts on the Concept of Animal Rights”. Journal International de Bioéthique, vol. 24, no. 1, pp. 77-85.

Chrulew, M., Wadiwel, D. J. (eds.) (2017). Foucault and Animals. Leiden - Boston: Brill.

Coals, P., Burnham, D., Loveridge, A., et al. (2019). "The Ethics of Human-Animal Relationships and Public Discourse: A Case Study of Lions Bred for Their Bones”. Animals, vol. 9, no. 2, art. no. 52. DOI: 10.3390/ani9020052

Derrida, J. (2008). The Animal That Therefore I Am, translated by D. Willis. New York: Fordham University Press.

Fichte, J. G. (1979). Grundlage des Naturrechts. Hamburg: Felix Meiner Verlag.

Fieldhouse, H. (2004). "The Failure of Kantian Theory of Indirect Duties to Animals". Animal Liberation Philosophy and Policy Journal, vol. 2, pp. 1-9.

Foot, P. (2001). Natural Goodness. Oxford: Clarendon Press.

Forst, R. (1999). "The Basic Right to Justification: Toward a Constructivist Conception of Human Rights", Constellations, vol. 6, no. 1, pp. 35-60.

Garner, R. (2016). "Animal Rights and the Deliberative Turn in Democratic Theory". European Journal of Political Theory, vol. 18, no. 3, pp. 309-329. DOI: 10.1177/1474885116630937

\footnotetext{
${ }^{11}$ Especially if a handful of questions will be taken into ethical consideration: "Very generally, all animals deserve ethical consideration, meaning ethically informed concern for the types of lives they are trying to lead. The list directs our attention to a host of pertinent factors. What life span is normal for that species in the wild? What is the physical condition of a healthy animal? What human acts invade or impair the bodily integrity of that sort of animal? What types of movement from place to place are normal and pleasurable for that sort of animal? What types of sensory and imaginative stimulation does this animal seek, and what is it to keep that animal in an unacceptably deficient sensory environment? What is it for that sort of animal to live in crippling and intolerable fear or depression, or with a lack of bonds of concern? What types of affiliations does this animal seek in the wild, what sorts of groups, both reproductive and social, does it form? What types of communication does the animal engage in, using what sensory modalities? What is it for the animal to be humiliated and not respected? What is it for this animal to play and enjoy itself? Does the animal have meaningful relationships with other species and the world of nature? What types of objects does this animal use and need to control if it is to live its life?" (Nussbaum, 2018: 10).
} 
Garner, R. (2008). "The Politics of Animal Rights". British Politics, vol. 3(1), pp. 1105-119.

Garner, R. (ed.) (1996). Animal Rights. The Changing Debate. London: Palgrave Macmillan Press Ltd.

Gosling, S. D. (2001). "From Mice to Men: What Can We Learn About Personality from Animal Research?" Psychological Bulletin, vol. 127, no. 1, pp. 45-86.

Grey, J. (2013). "'Use Them at Our Pleasure': Spinoza on Animal Ethics". History of Philosophy Quarterly, vol. 30, no. 4, pp. 367-388.

Grondin, J. (2007). "Derrida on the Question of the Animal". Cités, vol. 7, no. 2, pp. 31-39.

Habermas, J. (1983). Moralbewusstsein und kommunikatives Handeln. Frankfurt am Main: Suhrkamp.

Habermas, J. (1990). Moral Consciousness and Communicative Action, translated by T. McCarthy. Cambridge: Polity Press.

Habermas, J. (1993). Justification and Application. Cambridge: The MIT Press.

Habermas, J. (1994). "Remarks on Discourse Ethics", in: Habermas, J., Justification and Application. Remarks on Discourse Ethics, translated by C. Cronin. Cambridge: The MIT Press.

Habermas, J. (1996). Between Facts and Norm, translated by W. Rehg. Cambridge: The MIT Press.

Habermas, J. (2010). "Human Dignity and the Realistic Utopia of Human Rights". Metaphilosophy, vol. 41, no. 4, pp. 464-480.

Hodgeson, L.-M. (2010). „Kant on the Right to Freedom: A Defense”. Ethics, vol. 120, pp. 791-819.

Horster, D. (1989). „Die Wirklichkeit der Freiheit“. Archiv für Rechts- und Sozialphilosophie, vol. 75 (2), pp. 145-160.

Jonas, H. (1987). „Warum die Technik ein Gegenstand für die Ethik ist: Fünf Gründe”, in: Lenk, H., Ropohl, G. (eds.), Technik und Ethik. Stuttgart: Philipp Reclam jun., pp. 81-91.

Jonas, H. (2015). Das Prinzip Verantwortung, in: Kritische Gesamtausgabe der Werke von Hans Jonas, Mit Unterstützung des Hans Jonas-Zentrums e.V., herausgegeben von D. Böhler et al., vol. I. KGA, Bd. I/2. Freiburg i.Br.-Berlin-Wien: Rombach Verlag.

Jonas, H. (2016). „The Basic Forms of Organic Existence: Metabolism”, in: Beckers, J. O., Preußger, F. (eds.), Organism and Freedom. An Essay in Philosophical Biology KGA Bd. I/4, Freiburg i.Br.Berlin-Wien: Rombach Verlag, pp. 1-69.

Kaniowski, A. M. (2004). "Filozofia praktyczna Immanuela Kanta - jej siła i słabości”. Diametros, vol. 2, pp. 114-126.

Kant, I. (2013). "Conjectural Beginning of Human History", in: idem, Anthropology, History, and Education. Ed. by Zöller, G., Louden, R. B.; translated by Gregor, M. et al. Cambridge University Press, pp. 163-175.

Kelly, E. (2011). Material Ethics of Value: Max Scheler and Nicolai Hartmann. Dordrecht-HeidelbergLondon-New York: Springer.

Keulartz, J., van der Weele, C. (2009). „Between Nativism and Cosmopolitanism: Framing and Reframing in Invasion Biology“, in: Drenthen, M. A., Keulartz, J. F. W., Proctor, J. (eds.), New Visions of Nature, Complexity and Authenticity. Dordrecht-Heidelberg-London-New York: Springer, pp. 237-256.

Korsgaard, Ch. (1989). „Personal Identity and the Unity of Agency: A Kantian Response to Parfit”. Philosophy \& Public Affairs, vol. 18, no. 2, pp. 101-132.

Korsgaard, Ch. (2013). "Personhood, Animals and the Law". Think, vol. 12(34), pp. 25-32.

Korsgaard, Ch. (2014). "The Normative Constitution of Agency”, in: Vargas, M., Yaffe, G. (eds.), Rational and Social Agency: The Philosophy of Michael Bratman. Oxford Scholarship Online. DOI:10.1093/acprof:oso/9780199794515.003.0009

Łuków, P. (2004). „Komentarz do tekstu Andrzeja M. Kaniowskiego pt. Filozofia praktyczna Immanuela Kanta - jej siła i stabości”. Diametros, vol. 2, pp. 137-47.

McCarthy, T. (1978). The Critical Theory of Jürgen Habermas. MIT Press: Cambridge. 
Mendieta, E. (2011). „Interspecies Cosmopolitanism: Towards a Discourse Ethics Grounding of Animal Rights". Logos. A Journal of Modern Society and Culture, vol. 10, no. 1. http://www.logosjournal.com/interspecies-cosmopolitanism.php

Mill, J. S. (1987). "Whewell on Moral Philosophy", in: Mill, J. S., Bentham, J., Utilitarianism and Other Essays. New York: Penguin Books.

Morar, M. (2008). "The Limits of Discourse Ethics Concerning the Responsibility Toward Nature, Nonhuman Animals and Future Generations”, in: Olaru, B. (ed.), Autonomy, Responsibility and Health Care. Critical Reflections. Bocharest: Zeta Books, pp. 129-158.

Mulia, P. et al. (2018). "The Moral Imperatives of Sustainable Development: A Kantian Overview". Problems of Sustainable Development, vol. 13, no. 2, pp. 77-82.

Neumann, I. D. et al. (2011). „Animal Models of Depression and Anxiety: What Do They Tell Us about Human Condition?". Progress in Neuro-Psychopharmacology and Biological Psychiatry, vol. 35, pp. 1357-1375. DOI: 10.1016/j.pnpbp.2010.11.028

Nowak, E. (2021), “Can We Justify Animal Rights with Hegel's Thought?” Paper presented on the XXXIII International Hegel-Congress Hegel and Freedom, Warsaw, 21-25 June 2021.

Nussbaum, M. (2004). "Beyond 'Compassion and Humanity': Justice for Nonhuman Animals", in: Sunstein, C. R., Nussbaum, M. C. (eds.), Animal Rights. Current Debates and New Directions Oxford: Oxford University Press, pp. 299-320.

Nussbaum, M. (2006). Frontiers of Justice: Disability, Nationality, Species Membership. Cambridge, MA: The Belknap Press.

Nussbaum, M. (2018). „Working with and for Animals. Getting the Theoretical Framework Right”. Journal of Human Development and Capabilities, vol. 19, no. 1, pp. 218.

Nussbaum, M. C. (2001). "Animal Rights: The Need for a Theoretical Basis", Review of Rattling the Cage: Toward Legal Rights for Animals, by S. M. Wise”. Harvard Law Review, vol. 114, pp. 15061549 .

Patzig, G. (1984). "Ökologische Ethik innerhalb der Grenzen der bloßen Vernunft”, in: Elster, H. J. (ed.), Umweltschutz. Herausforderungen unserer Generation. Mainz: Hase \& Koehler.

Pietrzykowski, T. (2019). „Animal Rights: Ethics, Society and Constitutions”. Society Register, vol. 3, no. 3, pp. $151-158$.

Powell, D. M., Gartner, M. C. (2011). „Applications of Personality to the Management and Conservation of Nonhuman Animals", in: Inoue-Murayama, M., Kawamura, S., Weiss, A. (eds.), From Genes to Animal Behavior: Social Structures, Personalities, Communication by Color. Tokyo: Springer, pp. 185-199.

Probucka, D. (2017). „European Philosophy and Its Negative Impact on the Treatment of Animals”. Zoophilologica. Polish Journal of Animal Studies, vol. 3, pp. 155-162.

Probucka, D. (2018). "On the Concept of Ecological Solidarity. What Connects Animal Rights with the Rights of Human Beings?" Humanistyka i Przyrodoznawstwo, vol. 24, pp. 39-47.

Puryear, S. 2017. „Schopenhauer on the Rights of Animals”. European Journal of Philosophy. DOI: 10.1111/ejop.12237

Rawls, J. (1971). The Theory of Justice. Cambridge, MA: Harvard University Press.

Regan, T. (1983). The Case for Animal Rights. Berkeley: University of California Press.

Regan, T. (2010). „Animals as Subjects-of-a-Life”, in: Keller, D. R. (ed.), Environmental Ethics. The Big Questions. Chichester, UK: Wiley-Blackwell Publishing Ltd, pp. 161-168.

Richter, S. H., Hintze, S. (2019). „From the Individual to the Population - and Back Again? Emphasizing the Role of the Individual in Animal Welfare Science". Applied Animal Behaviour Science, vol. 212, pp. 1-8.

Rowlands, M. (2012). Can Animals Be Moral? New York: Oxford University Press.

Rowlands, M. (2016). “Are Animals Persons?”, Animal Sentience, vol. 101, pp. 1-12. 
Rutherford, D. (2008). „Spinoza and the Dictates of Reason”. Inquiry. An Interdisciplinary Journal of Philosophy, vol. 51, no. 5, pp. 485-511.

Rutherford, D. (2010). "Spinoza's Conception of Law: Metaphysics and Ethics", in: Melamed, Y. Y., Rosenthal, M. A. (eds.), Spinoza's 'Theological-Political Treatise': A Critical Guide. Cambridge University Press.

Sankoff, H., (2012). "The Animal Rights Debate and the Expansion of Public Discourse: It Is Possible for the Law Protecting Animals to Simultaneously Fail and Succeed?" Animal Law, vol. 18, pp. 281320.

Schinkel, A. (2008). „Martha Nussbaum on Animal Rights“. Ethics and Environment, vol. 13, no. 1, pp. 41-69.

Siemek, M. (2021). Inedita. Warszawa: Wydawnictwa Uniwersytetu Warszawskiego.

Singer, P. (1978). „Animal Experimentation“, in: Reich, W. T. (ed.), Encyclopedia of Bioethics, vol. 1, London-New York: Collier Macmillan Publishers, pp. 79-83.

Skidmore, J. (2001). "Duties to Animals: The Failure of Kant's Moral Theory". Journal of Value Inquiry, vol. 35, pp. 541-559.

Somek, A. (2016). „Zur Rekonstruktion des Rechts (2): Die Prinzipien des Rechtsstaates”, in: Koller, P., Hiebaum, Ch. (eds.), Jürgen Habermas: Faktizität und Geltung. Berlin - Boston: De Gruyter.

Stilt, K. (2021). "Rights of Nature, Rights of Animals". Harvard Law Review Forum, vol. 134, s. 276285.

Sunstein, C. (2002). „The Rights of Animals: A Very Short Primer“. University of Chicago Public Law \& Legal Theory Working Paper, no. 30, n.p. https://papers.ssrn.com/sol3/papers.cfm?abstract_id=323661

Swan, D., McCarthy, J. (2003). "Contesting Animal Rights on the Internet: Discourse Analysis of the Social Construction of Argument". Journal of Language and Social Psychology, vol. 22, no. 3, pp. 297-320.

Thompson, M. (2011). "Enlarging the Sphere of Recognition: A Hegelian Approach to Animal Rights". The Journal of Value Inquiry, vol. 45, pp. 319-335.

Thompson, M. (2012). Life and Action. Elementary Structures of Practice and Practical Thought. Cambridge: Harvard University Press.

Ward, A. J. et al. (2020). "Social Recognition and Social Attraction in Group-Living Fishes". Frontiers in Ecology and Evolution, vol. 8, no. 15, pp. 1-16. DOI: 10.3389/fevo.2020.00015

Whitaker, A. M., Gilpin, N. W., Edwards, S. (2014). “Animal Models of Post-Traumatic Stress Disorder and Recent Neurobiological Insights". Behavioural Pharmacology, vol. 25, pp. 398-409. DOI: 10.1097/FBP.0000000000000069

Whitebook, J. (1979). "The Problem of Nature in Habermas". Telos, vol. 40, pp. 41-69.

Wilson, M. (1999). "'For They Do Not Agree in Nature with Us': Spinoza on the Lower Animals", in: Gennaro, R. J., Huenemann, C. (eds.), New Essays on the Rationalists. Princeton-NJ: Princeton University Press, pp. 336-352. 